\title{
DAMPAK MEDIA INTERNET TERHADAP PERILAKU SISWA KELAS VIII Di SMPN 2 KINALI KECAMATAN KINALI KABUPATEN PASAMAN BARAT
}

\author{
Ridho Herwindo \\ Program Studi Pendidikan Geografi \\ FIS Universitas Negeri Padang \\ email: ridhoherwindo@gmail.com
}

\begin{abstract}
Abstrak
Penelitian ini bertujuan untuk mendeskripsikan dampak media internet terhadap perilaku siswa kelas VIII SMPN 2 Kinali Kecamatan Kinali Kabupaten Pasaman Barat yang dilihat dari cara siswa mengakses internet, situs apa yang sering dikunjungi oleh siswa, dan dampak media internet terhadap prilaku siswa. Jenis penelitian ini adalah deskriptif kualitatif. Subjek penelitian adalah siswa kelas VIII SMPN 2 Kinali sebanyak 20 orang dengan menggunakan teknik purposive sampling. Teknik pengumpulan data adalah observasi, wawancara dan dokumentasi. Teknik analisis data dengan langkah langkah reduksi data, penyajian data dan penarikan kesimpulan. Hasil penelitian menemukan: (1) Media yang sering kali digunakan peserta didik saat mengakses internet menggunakan handphone, karena dengan handphone akses internet menjadi mudah,bisa mengakses internet kapan saja dan dimana saja sedangkan bagi siswa yang tidak mempunyai handphone bisa mengakses internet dengan pergi mengunjungi warnet. (2) Website atau situs yang sering dikunjungi siswa yaitu wikipedia, website sosial media seperti facebook, instagram, twitter, youtube, dan situs permainan game online seperti game online pointblank, zynga poker, dan dragonest, mereka tidak memanfaatkan internet untuk menunjang pembelajaran di sekolah melainkan memanfaatkan internet untuk hal yang tidak penting. (3) Dampak media internet terhadap perilaku siswa,ada yang bersifat positif dan ada yang bersifat negatif. Dampak positif media internet terhadap pe rilaku, gaya style berpakaian yang semakin update dan tidak kolot, penampilan yang semakin menarik, meningkatkan kreatifitas siswa, sedangkan dampak negatif internet kecanduan bermain game online, banyak game yang ada unsur perjudian, tayangan yang berisikan konten dewasa membuat siswa secara tidak langsung juga meniru dari tayangan yang mereka lihat, suka berbohong dan menimbulkan rasa malas.
\end{abstract}

Kata Kunci:Dampak, Media Internet, Perilaku Siswa

\begin{abstract}
The aims ofresearch were to describethe impact of internet media on the behavior of students of class VIII SMP Negeri 2 Kinali District of Kinali West Pasaman District viewed from the way student students access the internet, what sites are often visited by students. The type of research is descriptive qualitative. Determination of informant using purposive sampling technique. Data technique is observation, interview and documentation. The results of the study found: (1) The rapid development of technology for students to access the internet, not only using the wifi network that is not available in schools can access the internet using mobile phones or smartphones, for students who do not have mobile phones can access the internet by going Cafe, Which costs relatively cheaper than internet access via mobile phone or smartphone. (2) Websites or sites that are often visited by SMPN 2 Kinali students are social media websites such as facebook, instagram, twitter, youtube, and online game sites such as pointblank online game, zynga poker, and dragonest, SMPN 2 Kinali. The Internet is only to seek information that is not important, not using the internet to support learning in school. (3) The impact of internet media on student behavior, there are positive and there are negative. The positive impact of internet media on behavior, style of clothing that is increasingly updated and not conservative, the appearance of the more interesting, increasing the creativity of students, while the negative impact of internet addiction to play online games, many games that have elements of gambling, impressions containing adult content to make students indirectly also imitate from the impressions they see, likes to lie and cause a sense of laziness.
\end{abstract}

Key Word:Impact, Internet Media, Student Behavior

Artikel ini ditulis dari skripsi dengan judul Dampak Media Internet Terhadap Perilaku Siswa Siswi Kelas VIII SMPN 2 Kinali Kecamatan Kinali Kabupaten Pasaman Barat oleh Ridho Herwindo 


\section{PENDAHULUAN}

Perkembangan teknologi informasi yang semakin pesat dan komputer menjadi salah satu kebutuhan yang diperlukan di dalam kehidupan sehari-hari, tak terkecuali di dalam dunia pendidikan. Siswa dituntut untuk lebih mengenal teknologi sehingga dapat meningkatkan kegiatan belajar mengajar yang yang ada di dalam lingkungan sekolah tersebut.

Saat ini kreatifitas dibutuhkan oleh para siswa untuk menghadapi era yang akan datang karena persaingan dalam berbagai hal akan sangat berat dan jika membiasakan diri untuk berfikir kreatif maka akan terbiasa untuk keadaan yang menuntut untuk berpikir lebih keras lagi. Karena dengan berfikir kreatif dapat melakukan suatu hal dengan lebih baik atau bahkan mendapatkan hal yang baru dengan berfikir kreatif.

Melihat hal tersebut banyak sekolah-sekolah yang menggunakan teknologi komputer bertujuan untuk meningkatkan kualitas siswa disekoalah tersebut. Internet menjadi salah satu pilihan yang digunakan untuk mendukung hal tersebut, internet sendiri adalah salah satu teknologi yang saat ini dan paling popular serta banyak digunakan oleh masyrakat baik di Indonesia maupun luar.

Pihak sekolah maupun orang tua menganggap bahwa dengan mengenalkan internet dengan lebih dini kepada anak ataupun siswa maka pola pikir siswa pun akan menjadi lebih berkembang sehingga menimbulkan kreativitas anak ataupun siswa. Ada banyak hal baru yang diperoleh dengan berpikir kreatif dan banyak pula yang dibutuhkan untuk berpikir kreatif.

Secara psikologi menurut Akbar (2001:55) "kreatif adalah sebagai proses munculnya hasil-hasil baru ke dalam suatu tindakan. Hal baru itu muncul dari sifat unik, yang berinteraksi dengan orang-orang, pengalaman maupun keadaan hidupnya". Kreativitas tidak datang dengan sendirinya dan diperlukan pendukung lainnya untuk menghasilkan suatu kreativitas. Salah satunya adalah teknologi, dimana saat ini banyak hal yang dapat dilakukan dengan bantuan teknologi dan teknologi internet lah yang dianggap cocok untuk mendukung.

Remaja sebagai pengguna internet telah banyak mendapatkan hal-hal yang baru sehingga informasi yang didapat semakin banyak dan pengetahuan semakin banyak. Dalam UU No. 11 Tahun 2008 Tentang Informasi Dan Transaksi Elektronik pada pasal 27 ayat 1-3 disebutkan bahwa:(1) Setiap orang dengan sengaja dan tanpa hak mendistribusikan dan/atau mentransmisikan dan/atau membuat dapat diaksesnya informasi elektronik dan/atau dokumen elektronik yang memiliki muatan yang melanggar kesusilaan., (2) setiap orang dengan sengaja dan tanpa hak mendistribusikan dan menstransmisikan membuat dapat 
diaksesnya infotmasi elektronik memiliki muatan judi, (3) setiap orang dengan sengaja dan tanpa hak mendistribusikan dan/atau mentransmisikan dan/atau membuat dapat diaksesnya informasi elektronik dan/atau dokumen elektronik yang memiliki muatan penghinaan dan/atau pencemaran nama baik.

Permasalahan saat ini banyak siswa yang menyalah gunakan pemanfaatan dari media internet, seperti menonton tayangan yang di akses dari internet tersebut tidak pantas atau bisa saja menonton tayangan yang vulgar yang berbau pornografi. Begitu banyak kasuskasus pelanggaran hukum yang terjadi baik di lingkungan sekolah atau lingkungan masyarakat akibat penyalahgunaan IPTEK khususnya dalam penggunaan internet. Seperti maraknya kasus yang penulis temukan pada saat melakukan observasi awal dimana saat proses belajar mengajar berlangsung ditemukan beberapa siswa dan siswi SMP yang sibuk bermain handphone pada saat jam pelajaran sudah dimulai dengan berbagai fasilitas jejaringan sosial yang tersedia para siswa dan siswi ini sibuk dengan handphone mereka masing- masing tanpa mempedulikan guru menerangkan materi pelajaran. Ada juga siswa dan siswi yang sibuk membulli temannya akibat menonton tayangan yang tidak sepantasnya ditiru pada jejaring media sosial yang mereka punya sehingga mereka mempraktekkan hal yang tidak sepantasnya itu pada teman- teman sebaya mereka, bahkan di sekitar lingkungan sekolah ada beberapa siswa yang ditemukan kedapatan sedang merokok.

Berdasarkan data yang didapatkan dari dinas pendidikan Kabupaten Pasaman Barat terdapat jumlah anak yang putus sekolah ditahun 2014 di Kecamatan Kinali sebanyak 215 orang hal ini dikarenakan tidak mempedulikan pendidikan, mereka hanya memikirkan kesenangan yang mereka peroleh pada saat ini, lantaran sibuk menghabiskan waktu untuk bermain game online dan mengakses situs-situs intenet sehingga lupa akan sekolah.

Fungsi media internet bagi individu dapat dilihat dari beberapa hal yaitu kepuasan, kesenangan, dan pemakaian yang mencerminkan tingkat keteraturan dan prediksibiklitas, fungsi internet bagi individu dapat dilihat dari fungsi media massa bagi individu McQuail dalam Sushane (2008:69) yaitu : (a) Mencari berita tentang peristiwa, kondisi yang berkaitan dengan lingkungan terdekat, masyarakat, dan dunia. (b) Mencari bimbingan menyangkut berbagai masalah praktis. (c) Memuaskan rasa ingin tahu. (d) Memperoleh rasa damai melalui penambahan pengetahuan. Siswa dapat memperoleh informasi yang diinginkanya baik informasi akademik maupun nonakademik melalui internet, selain itu 
keberadaan internet yang dapat menyuguhkan fasilitas yang menarik yang mana berfungsi sebagai media hiburan.

Internet sangat memberikan pengaruh positif bagi siswa, kemajuan dunia informasi memberikan manfaat positif dan internet pada keberadaan internet. Banyak pelajar yang mendapatkan ilmu dengan bantuan internet. Bahkan tugas-tugas sekolah kini terasa lebih mudah dengan mencarinya di internet. Kalau dulu, orang harus membuka berbagai jenis buku dan koran untuk mencari tahu tentang suatu info. Atau dengan menyimak radio dan tv, tapi kini cukup dengan bantuan internet, semua info seakan membanjir. Banyak pelajar yang sudah mahir dengan manfaat dan kegunaan situs-situs tertentu cukup dengan ke wikpedia misalnya, sesuatu masalah telah terselesaikan, mereka juga dengan mudahnya googling untuk mencari tugas dari sekolah.

Aktivitas-aktivitas internet yang dilakukan para pengguna internet menjadi empat kelompok kepentingan penggunaan internet yaitu : (a) Email, (b) Aktivitas kesenenangan / fun activities, yaitu aktivitas yang sifatnya untuk kesenangan atau hiburan seperti : online untuk bersenang-senang, klip video atau audio, pesan singkat, mendengarkan atau mengunduh musik, bermain game, chatting. (c) kepentingan informasi yaitu aktivitas internet untuk mencari informasi, seperti ; informasi produk, informasi travel, cuaca, informasi tentang film, music, buku, berita, sekolah dan informasi tentang politik. transaksi yaitu transaksi jual beli melalui internet. Selain mempermudah tugas sekolah, internet juga membantu pelajar untuk mengembangkan diri. Mereka bisa tahu tentang info pelajar, info lomba, dan berbagai info bermanfaat lainnya. Pelajar juga dapat menggunakan internet untuk membuka wawasan dan memperluas pergaulan mereka. Mereka dapat berteman dengan siapa saja dari mana saja.

Dampak positif internet terhadap pelajar sangat besar, bisa diketahui bahwa semakin lama penggunaan internet bagi pelajar terutama pada kalangan sekolah menengah pertama dan sekolah atas. Fasilitas internet seperti e-mail, situs web (www), YM (yahoo massengger), dan jejaring sosial facebook sudah sangat popular diantara pelajar, baik sebagai sarana komunikasi maupun alat untuk mencari data juga sebagai alat untuk memperluas pergaulan dan perkenalan antar pengguna intenet.

Karena dampak positif intenet bagi pelajar sangat banyak, menggunakan intenet sebagai sarana komunikasi yang tercepat dan tercanggih untuk saat ini dengan resiko menerima dampak negatifnya. Menurut Annisa Rahmania (2010:26) dampak negatif yang ditimbulkan 
oleh internet sebagai berikut : 1. Beberapa berita melansir adanya penculikan anak atau kasus pelarian anak di bawah umur yang masih berstatus pelajar yang berawal dari situs pertemanan atau jejaring sosial facebook diinternet. Sifat siswa yang murah percaya pada siapapun memungkinkan terjadinya hal tersebut.

2.Pornografi adalah pengaruh internet lainnya, istilah pornografi sudah melekat dengan internet. Anggapan yang menyatakan bahwa internet identik dengan pornografi memang tidak salah, meskipun tidak sepenuhnya benar, dengan jangkauan luas yang dimiliki internet, pornografi merajalela. Banyaknya situs-situs porno yang beredar membuat setiap yang mengakses internet berkesempatan untuk menyaksikan yang berbau pornografi, terkadang niatnya hanya mencari tugas lantaran ada iklaniklan yang fulgar, siswa langsung melihat dan menonton hal yang tidak sewajarnya

ditonton.

3. Perjudian dengan jaringan yang tersedia para penjudi tidak perlu pergi ke tempat khusus untuk memenuhi kebutuhannya, mereka bisa bebas melakukan perjudian di internet tanpa terawasi. Mulai dari situs taruhan bola, judi kasino, sampai permainan togel yang dilarang di dunia nyata. 4. Kecanduan permainan online yang melanda para pelajar juga merupakan pengaruh negatif internet. Kecanduan dan ketergantungan dapat membuat pelajar kehabisan waktu dan energy untuk bermain. Jika para pelajar terlalu sering bermain game online bahkan setiap hari, tidak menutup kemungkinan waktu belajar berkurang, sehingga hasil belajarnya menurun.

5. Jejaring sosial yang banyak memberikan dampak yang tidak baik terhadap siswa, jejaring sosial youtube yang bisa menonton videovideo yang berbau fulgar dan pornografi. Semenjak situs jejaring sosial banyak diminati para siswa rela menghabiskan waktu berjamjam hanya untuk mengunjungi situs tersebut, sosial media membuat setiap orang cenderung bersifat individu.

6. Boros, akses internet khususnya untuk membuka website atau situssitus tertentu jelas berpengaruh terhadap kondisi keuangan (terlebih kalau akses dari warnet) ini sudah bisa dikategorikan sebagai pemborosan karena tidak produktif. Banyak di sekitar sekolah-sekolah terdapat warnet, sehingga siswa siswi hanya menghabiskan duit jajan di warnet tersebut, tidak bisa lagi menabung dan menyisihkan duit jajan, lantaran terlalu asyik untuk mengakses media internet di warnet.

Begitu banyak dampak negatif maupun positif yang diperoleh melalui media internet dikalangan masyarakat khususnya bagi siswa dan siswi di sekolah. Pada uraian dalam latar belakang di atas, maka penulis melakukan penelitian dengan judul "Dampak Media 
Internet Terhadap Perilaku Siswa Siswi Kelas VIIISMP Negeri 2 Kinali Kecamatan Kinali Kabupaten Pasaman Barat”.

\section{METODE PENELITIAN}

Penelitian ini merupakan penelitian deskriptif menggunakan pendekatan kualitatif yakni penulisan yang didasarkan pada pandangan mereka yang diteliti dengan rinci, dibentuk dengan kata-kata,gambaran holistik dan rumit (Moleong, 2007:6). Penelitiandilakukan di SMPN 2 Kinali Kecamatan Kinali Kabupaten Pasaman Barat. Teknik penentuan informan menggunakan teknik purposive sampling. Analisis data yang digunakan dalam penelitian ini adalah model analisis data yang dikemukakan oleh Miles dan Huberman dalam Sugiyono (2012:92) yaitu; (a) mengumpulkan data dari berbagai sumber melalui wawancara dan pengamatan langsung tentang media yang digunakan oleh siswa, website yang sering dikunjungi oleh siswa, dan dampak media internet terhadap perilaku siswa. (b) Reduksi data yaitu memilih hal-hal yang pokok sesuai dengan fokus penelitian kemudian mencari temanya. (c) Penyajian data (display data) adalah penyajian data dalam bentuk tulisan dan tabel. (d) Penarikan kesimpulan dilakukan dengan cara menggabungkan dan menganalisis data yang didapat di lapangan melalui hasil wawancara observasi dan dokumentasi.

\section{HASIL PENELITIAN}

Hasil penelitian mengenai dampak media internet terhadap perilaku siswa siswi kelas VIII SMP Negeri 2 Kinali Kecamatan Kinali Kabupaten Pasaman Barat sebagai berikut:

\section{Cara Siswa Mengakses Internet}

Banyak cara untuk mengkases internet, kebanyakan siswa kelas VIII di SMPN 2 Kinali mengkases internet melalui handphone maupun pergi ke warnet untuk mendapatkan informasi data yang dicari, bagi siswa yang tidak memiliki handphone bisa kewarnet untuk mengkases internet. Untuk mengakses media internet banyak siswa menggunakan handphone, dari pada pergi ke warnet, handphone yang sudah difasilitasi untuk mengakses internet memberikan banyak kemudahan untuk mendapatkan informasi yang dicari, dan siswa-siswi juga bisa mengakses internet kapanpun dan dimanapun dari pada pergi ke warnet.

\section{Situs atau Website yang sering Dikunjungi \\ Pada dasarnya siswa} mengakses internet bertujuan untuk mencari data, informasi, bahan pelajaran maupun hiburan-hiburan yang ada, banyak aktivitas siswa yang seringkali menggunakan media internet seperti bermain media sosial, mengerjakan tugas sekolah, dan 
masih banyak website atau situs-situs yang banyak memberikan informasi dengan cepat maupun hiburan.

Siswa-siswi SMPN 2 Kinali banyak mengakses situs media sosial seperti facebook, twitter, instagram, youtube, untuk hiburan semata. bahkan dari facebook juga banyak beragam macam game-game yang ada didalamnya seperti game bliyard, zynga poker, dan game online lainnya, beberapa siswa juga mengakses situs wikipedia untuk mencari tugas pengetahuan yang diberikan di sekolah Website atau situs yang dikunjungi memberikan banyak informasi secara cepat hal ini membuktikan bahwa tidak setiap website atau situs yang dikunjungi siswa-siswi SMPN 2 Kinali sifatnya bermanfaat atau mendidik.

\section{Dampak Media Internet terhadap Perilaku Siswa}

Dampak media Internet terhadap perilaku yang baik maupun dampak yang buruk dikalangan siswa SMPN 2 Kinali, internet memberikan kemudahan untuk mengerjakan sesuatu yang sulit, seperti mengerjakan tugas yang dianggap sulit bagi siswa SMPN 2 Kinali, serta memberikan dampak yang kurang baik terhadap perilaku dan berdampak terhadap gaya style berpakaian, cara berkomunikasi maupun berdampak buruk bagi kesehatan, terlalu sering menatap layar monitor komputer juga berdampak tidak baik terhadap kesehatan mata, mata menjadi kabur, serta kurangnya konsentrasi saat belajar.

Banyak dampak positif maupun negatif saat mengakses internet, kecanduan internet membuat siswa diakalangan SMPN 2 Kinali membuang waktu dengan percuma, waktu yang seharusnya bisa untuk belajar digunakan untuk bermain game online, serta gaya pergaulan yang terlalu bebas karena meniru kebiasaan yang ada dipostingan facebook, youtube, maupun instagram membuat siswa menjadi pribadi yang tidak sesuai dengan nilai dan norma yang berlaku ditengah-tengah lingkungan masyarakat.

\section{PEMBAHASAN}

Berdasarkan hasil penelitian maka diperoleh gambaran sebagai berikut:

\section{Cara Siswa Mengakses Internet}

Ada bebeberapa cara bagi siswa siswi kelas VIII SMPN 2 kinali untuk mengakses media internet, dengan media smartphone atau handphone dan pergi ke warnet atau biasa dikenal dengan warung internet, bagi para siswa yang tidak mempunyai handphone biasanya pergi kewarnet untuk mengakses media internet, tidak seperti kota kota besar lainnya setiap sekolah sudah difasilitasi dengan jaringan internet yang gratis atau biasa dikenal dengan jaringan wifi, di SMPN 2 Kinali belum difasilitasi dengan jaringan wifi, sehingga siswa harus menggunakan smartphone atau handphone untuk mengakses internet 
dan membeli paket data internet sebelum mengakses internet.

Biasanya tarif yang dipasang diwarnet berbagai macam fariasinya, ada juga paket-paket tertentu untuk para member setia setiap warnet, tarif yang diletakkan relatif lebih murah sehingga para pengunjung warnet kian hari kian bertambah, hal ini dilakukan untuk meningkati minat para pengunjung warnet.

Penggunaan internet sendiri sudah menjadi sebuah trend tersendiri dikalangan siswa SMPN 2 Kinali, dengan mengakses internet banyak manfaat yang diperoleh mulai dari mencari informasi tentang pelajaran, style terkini, maupun hiburan-hiburan yang ada diinternet.

\section{Situs Website yang Sering Dikunjungi}

Dengan mengakses internet para siswa dapat mengunjungi situs situs yang ingin dikunjunginya seperti situs media sosial facebook, instagram twitter, wikipedia, google translate maupun situs untuk bermain game online yang telah banyak bisa dikunjungi, majunya teknologi membuat masyarakat banyak mengunjungi situs atau website yang sedang populer terutama dikalangan siswa siswi SMPN 2 Kinali.

Situs atau website yang sering dikujungi siswa SMPN 2 Kinali seperti situs media sosial, facebook, instagram, twitter, maupun youtube, sangat sering dikunjungi, bahkan selain situs media sosial yang sedang ramai dikunjungi itu terdapat juga situs game online yang sedang marak, game online memberikan kepuasan tersendiri bagi para pemainnya, terutama situs game online Pointblank atau dikenal dengan bermain $P B$, dan situs game online Dragonest.

Internet yang memberikan berbagai macam informasi yang mudah didapat dan diperoleh juga memberikan informasi yang tidak baik, bahkan membahayakan bagi kalangan pelajar khususnya siswa siswi kelas VIII SMPN 2 Kinali, website yang sering dikunjungi oleh siswa SMPN 2 Kinali sifatnya tidak ada yang mendidik bahkan tidak ada yang memberikan dampak untuk menunjang prestasi yang lebih baik, informasi yang mudah didapat dari website atau situs kebanyakan hanya bersifat hiburan semata.

\section{Dampak Media Internet terhadap} Perilaku Siswa

Selain dari mempermudah mendapatkan informasi dengan cepat internet juga memberikan dampak yang positif bagi pengunjung maupun dampak negatif, banyak dampak yang terjadi ketika mengkases internet contohnya saja saat mengakses media sosial, situs media sosial seperti facebook, twitter, instagram dan youtube dilihat dari segi keuntungannya memperbanyak teman, pergaulan, dan mengetahui kegiatan seseorang, terkadang didalam berbagai macam situs media sosial tersebut orangorang mengunggah foto-foto yang berbau pornografi, fulgar, hal ini 
dapat mempengaruhi psikologi para siswa.

Penggunaan internet tidak hanya bagi orang dewasa, melainkan dari anak sekolah sampai orang dewasa dapat menggunakan internet, termasuk penggunaan media sosial, bahkan penggunaan bahasa yang ada dimedia sosial terdengar tidak sopan, penggunaan bahasa tersebut terbawa ke lingkungan sekolah, sehingga siswa siswi banyak menggunakan kata-kata yang tidak sopan tersebut.

Banyaknya tayangan tayangan yang ada di situs media sosial seperti youtube, disitus youtube tersedia berjuta juta video dari video tentang pembelajaran sampai dengan tayangan video yang vulgar ada disitus youtube, siswa yang masih mencari jati diri terkadang salah menggunakan situs tersebut, dengan niat awal mencari video tentang pelajaran, salah fokus karena melihat cover tayangan yang tidak pantas disaksikan, tayangan tayangan yang membuat siswa menjadi dewasa sebelum waktunya karena melihat tayangan video yang ada diinternet.

$$
\text { Selain dampak dari }
$$

pengaksesan berbagai macam situs media sosial, game online yang ada diinternet juga memberikan dampak yang buruk, dan merusak kesehatan, siswa yang kecanduan bermain game online biasanya hanya menghabiskan waktu didepan layar monitor, dan membuang waktu dengan percuma bahkan sampai cabut dari sekolah hanya untuk bermain game online.
Pada umumnya siswa yang kecanduan akan bermain game online mengandalkan segala cara untuk bisa bermain game online, tidak mempunyai uang, mereka nekat mencuri untuk bisa bermain game online, bahkan setiap permainan game online yang dimainkan sikapnya tidak mendidik, bahkan permainan game online mengacu pada judi, secara tidak langusng permainan game online bisa dipertaruhkan dan ditukar dengan uang asli.

\section{KESIMPULAN DAN SARAN}

Berdasarkan temuan dan pembahasan hasil penelitian yang telahdikemukakan sebelumnya maka dapat diambil kesimpulan sebagai berikut:

1. Media yang digunakan siswa kelas VIII SMPN 2 Kinali saat mengakses internet Perkembangan teknologi yang semakin pesat mempermudah untuk mengakses internet, tidak hanya menggunakan jaringan wifi yang belum tersedia disekolah siswa bisa mengakses internet menggunakan handphone atau smartphone, bagi siswa yang tidak mempunyai handphone bisa mengakses internet dengan pergi mengunjungi warnet, yang biayanya relatif lebih murah dibandingkan mengakses internet melalui handphone atau smartphone.

2. Website atau situs yang sering dikunjungi siswa SMPN 2 Kinali 
yaitu website sosial media seperti facebook, instagram, twitter, youtube, dan situs permainan game online seperti game online pointblank, zynga poker, dan dragonest, siswa siswi di SMPN 2 Kinali memanfaatkan internet hanya untuk mencari informasi yang tidak penting, dan menggunakan internet tidak untuk menunjang pembelajaran disekolah.

3. Dampak media internet terhadap perilaku siswa kelas VIII SMPN 2 Kinali internet memberikan banyak dampak positif maupun negatif, tergantung bagaimana para siswa menyikapi cara pemakaian internet dengan aman dan tanpa membahayakan kebanyakan penggunaan internet dipergunakan untuk hal yang tidak tepat, banyak dampak negatif dari pada dampak positif saat mengakses internet tersebut, contohnya saja siswa menirukan apa yang mereka lihat dari tayangan tayangan yang mereka lihat diinternet, tayangan yang tidak pantas untuk ditiru atau dibawa kelingkungan sekolah, serta memberikan pengaruh yang buruk bagi kesehatan, seperti sakit mata karena sering berhadapan langsung dengan layar monitor.

\section{Saran}

Terdapat beberapa saran terkait dengan hasil penelitian yang telah dilakukan, diantaranya adalah :
1. Untuk sekolah hendaknya pihak sekolah memperhatikan pentingnya penggunaan media internet, sehingga bisa mempunyai jaringan internet sendiri seperti wifi untuk mendukung siswa mencari informasi pembelajaran supaya tidak menjadi gagap teknologi dibandingkan sekolah yang ada di kota kota besar.

2. Penelitian ini dapat menjadi bahan masukan kepada kepala sekolah SMPN 2 Kinali dan pemerintah terkait lainnya dalam mengantisipasi dampak negatif pengaruh media internet pada pelajar.

3. Diharapkan siswa khususnya di SMPN 2 Kinali agar dapat membentengi diri dari pengaruh negatif dari media internet yang dapat merusak moral dan akhlak akan tetapi melakukan kegiatan yang bersifat positif seperti bermain media internet tidak terlalu lama, mencari tugas sekolah dan tidak membuka situs-situs yang mengandung unsur pornografi dan sara.

4. Perlu sosialisasi internet akan bahaya dari dampak internet dari pihak sekolah. Meningkatkan imtak pendalaman agama melalui program di sekolah seperti melakukan wirid mingguan setiap hari Jumat dan ceramah agama.

5. Meningkatkan imtak pendalaman agama melalui program di sekolah seperti melakukan wirid mingguan setiap hari Jumat dan ceramah agama.

\section{DAFTAR PUSTAKA}


Akbar, Reni. 2011.Kreativitas. Jakarta : Gramedia Widiasarana Indonesia

Anna Rahmana, dkk. 2010. Internet Sehat Facebook dan Twitter. Depok : Penebar Plus

Arikunto, Suharismi. 2010. Manajemen Penelitian. Jakarta: Rineka Cipta

Moleong Lexy, J 2012. Metode Penelitian Kualitatif. Bandung : Remaja Rosdarkarya

Santoso, Threcy Whitny. 2013. Prilaku Kecanduan Permainan Internet dan Faktor Penyebabnya Pada Siswa Kelas VIII di SMPN 1 Jatisono. Kab.Wonoogiri. Semarang : Universitas Negeri Semarang

Sugiyono. 2012. Metode Penelitian Pendidikan. Bandung: Alfabeta

UU No. 11 Tahun 2008 Tentang Informasi Dan Transaksi Elektronik pada pasal 27 ayat 1 - 
